\title{
Causes and Consequences of Drug Abuse among Youth in Kwara State, Nigeria
}

\author{
Ifeoma P. Okafor
}

\begin{abstract}
Drug abuse is one of the health-related problems among Nigerian youth and has been a source of concern to educational stakeholders. Its social implications to undergraduate students cannot be quantified. In light of this, this study examined causes and consequences of drug abuse among undergraduates at the University of Ilorin, Kwara State, Nigeria. A descriptive survey design was adopted for the study and a simple random sampling technique was used to select the respondents for the study. The instrument used was a researcher-designed questionnaire on the causes and consequences of drug abuse among undergraduates. The instrument was validated by lecturers in the Department of Social Sciences Education and it possessed a coefficient of 0.72 using a test re-test method. All of the undergraduate students of the University of Ilorin formed the population of the study. The demographic data of the respondents and drug abuse variable were described and analyzed using percentages. Means were used to analyze the research question, while t-test and Analysis of Variance (ANOVA) were used to test the null hypotheses at a 0.05 level of significance. The findings of the study revealed that the major cause of drug abuse among undergraduates at the University of Ilorin was the need to cope with academic challenges. Findings also revealed that the main consequences of drug abuse among undergraduates of the University of Ilorin was low self-esteem. It was further revealed that there were no significant differences in the causes and consequences of drug abuse among undergraduates of the University of Ilorin based on gender and their faculty. It was, however, recommended among others that the government should enact measures on people that are selling drugs indiscriminately and should be supervising the target area, and if possible, check the activities of the victims of drug abuse. The Ministry of Education in conjunction with the National Campaign against Drug Abuse (NACADA) should engage in appropriate interagency agreements in order to streamline the provision of services to support students with social and behavioral problems emanating from drug abuse.
\end{abstract}

Ifeoma P. Okafor, Ph.D., a Lecturer in the Department of Social Sciences Education, University of Ilorin, Nigeria obtained her Doctor of Philosophy (Ph.D.) (2013) in Sociology of Education from the University of Ilorin, Nigeria. Okafor is a registered teacher with the Teachers' Registration Council of Nigeria (TRCN). She is a member of the Association of Sociologists of Education in Nigeria, the Social Studies Association of Nigeria, and the History of Education Society of Nigeria. Recent publications include: Okafor, I.P., Balogun, A. O., Iyekolo, O. A., Abdulaziz, I. \& Oniye, R. K. (2017). Socio-cultural factors and girl-child education in Nupe Land Nigeria Challenges of Access and Completion Rate. KIU Journal of Humanities. Published by the College of Humanities and Social Sciences Kampala International University ISSN2415-0843 (ISSN 2522-2821 online) 2 (1) 2B December 2017 79-89; Okafor, I.P., Balogun, A.O., Iyekolo, O.A., \& Isaka, Abdulaziz, (2017). Social deprivations and access to life-saving facilities among tertiary in Ilorin, Kwara State: African Journal of Interdisciplinary Studies, 10, 96-101. Published by the Department of Publishing and Web Development, University of Education, Winneba Ghana. 


\section{Introduction}

Drug abuse among Nigerian youth has been a scourge to the overall sustainable development of the nation. Substance abuse is a serious issue; a global and international issue particularly in developing countries like Nigeria. Drug abuse is also a major public health, social and individual problem and is seen as an aggravating factor for economic crises; hence, for Nigeria's poverty status. While youth are supposed to be the major agent of change and development, some of them have been destroyed by drug abuse (rendering them unproductive). Drug abuse has become a global concern in Nigeria because of its effect on youth and the nation as a whole. Drug abuse has a negative impact on the education of undergraduates in different universities across the globe. The overall health of the user is affected negatively and behaviours associated with drug abuse predispose the abuser to crime and contagious diseases including HIV/AIDS (Center for Disease Control, 2000).

Educational stakeholders like parents, teachers and the society at large are worried over the prevalence of drug abuse and its causes and consequences on the undergraduates of the University of Ilorin in Kwara State. Drugs are produced for a variety of different reasons including those associated with ensuring a state of wellbeing, curing illness, and sustaining mental and physical stability. Modern medical substances commonly known as 'medicine' (many derived from plants), do not constitute any danger. If properly administered, drugs can assist human beings in many positive ways. The term 'drug' refers to "any substance, when taken into a living organism, limits ill-health", however if drugs are abused, they can become very "destructive to the individual and to society at large". A drug is a chemical modifier of the living tissues that could bring about physiological, sociological and behavioural changes (Nnachi, 2007; Okoye, 2001).

Drugs, are substances which, when taken, can limit cognition, perception, mood, behaviour and overall body function. It can also produce a change in biological functions through its chemical actions (Balogun, 2006). A drug is used for reasons such as curing or alleviating pain and diagnosing ill-health and is seen as a common process in many communities. Studies by Kypri, Cronin and Wright (2005), and Melchior, Chastang, Goldberg and Fombonne (2008) submitted that across the countries of the world, drug abuse tends to be rampant among youngsters between the ages of 18 and 25 (the current age of university undergraduates).

Falco (2008) stated that the chronic use of drugs can cause serious damage, sometimes irreversible physical and social damage (either temporarily or for a long period of time). Internal damage could result as well. To this effect, some of these undergraduates, who are still in their growing stage, become insane, socially misfit in school situations and eventually drop out of school. The misuse of medication, self-medication and the use of illegal substances is called Drug Abuse. Some of these substances in the form of medication give pleasure to the user and some brain nerves becomes the end user (which is known as pleasurable pathways). The user at first may enjoy it and will want to experience the sensation again (Seraphim, 2005).

A person who allows himself/herself to be controlled by a psychoactive substance is called a 'drug abuser' (Merck, 2009). A drug abuser brings forth a condition called neurological functions and his/her moods, perception, consciousness, and energy levels change and the drugs can take over his/her normal functioning and well-being (King, 2008). The negligent use of any substance, mostly the ones that have effects on one's consciousness like alcohol, cocaine, codeine, and methamphetamines results in discomfort and malfunction (Merck, 2009).

The following habits were noted by Santrock (2001) and Nyaga (2001) by those who abuse substances - they exhibit watering eyes and nose, become abnormally talkative or 
unusually quiet, experience unpredictable tempers, their concentration lapses and they have a loss of interest in education. Some become careless, neglect their personal hygiene, become generally irresponsible, are highly irritable or hostile to close friends, and wear dirty and tattered clothes (or they do not change their clothes for many days). Santrock (2001) and Nyaga (2001) further stated that such behaviours present many challenges to school administrators.

In the early 1960s, after independence, Nigeria noticed rampant cases of drug abuse (Okon, 2002). During that period, the number of drugs that were mostly abused were limited to tobacco, kolanut and alcohol. These days, many young ones now resort to everything including tobacco, alcohol and illicit drugs; the products that are most available to them (Okon, 2002). This situation, among others, has resulted in the creation of the National Drug Law Enforcement Agency (NDLEA) which was established by Decree No. 48 in 1989 to handle issues relating to the abuse and trafficking of narcotic drugs and other psycho-tropic substances, other than food which by its chemical nature, affects the structure and function of living organisms (Fareo, 2012).

Many justifications have been attributed to the use of drugs especially among undergraduate students. In line with this, Olatude (2000) and Akunyili (2003) in their own views, stated that people use drugs for a variety of reasons which includes: 1) their the need to belong to a social group or class; 2) pressure from friends and peers; 3) for self-medication; 4) because of parental deprivation at various levels; 5) for pleasure; 6) to overcome illness; 7) to gain confidence; 8) to overcome shyness; 9) to be able to facilitate communication; 10) to overcome many other social problems; and 11) to induce themselves to work above their physical capacity.

Moreover, many people interchangeably use the concepts of 'drugs', 'drug misuse' and 'drug abuse', but there are definite differences between the concepts. Drug misuse is to use a drug for a purpose which it should not be used for. The misuse of drugs means following the medical instructions but the person may not necessarily be looking to 'get high' from their use. While drug abuse typically refers to those who do not have a prescription for what they are taking. Not only do they use it in a way other than it is prescribed but they also use it to experience the feelings associated with the drug. Euphoria, relaxation, the general feeling of 'getting high' is always associated with drug abuse. The abuse of drugs always results in unavoidable side effects, including dependency and addiction.

Nigeria introduced its drug control effort in 1985 when a dangerous drug ordinance was enacted to control trafficking and abuse (Johnson, 2002). By 1994, another landmark effort was made when the Federal Military Government promulgated the special tribunal (miscellaneous offences) Decree No. 20 of 1984 to stop drug trafficking within Nigeria shores. This is because a drug menace continued to rise in profile (Johnson, 2002). According to NAFDAC (2000), the following drugs were used and misused in Nigeria. They are stimulants, hallucinogens, sedatives, miscellaneous and tranquilizers.

a. Stimulants: These are substances that act and stimulate the central nervous system directly. The users of these substances at the initial stage experience pleasant effects such as energy increases. The major source of these comes from caffeine substances.

b. Hallucinogens: These are drugs that alter the sensory processing unit in the brain. They produce distorted perception, feelings of anxiety and euphoria, sadness and inner joy. They normally come from marijuana, LSD, etc. 
c. Narcotics: These drugs relieve pain, induces sleep and are addictive. They are found in heroin, codeine, opium, etc.

d. Sedatives: These drugs are among the most widely used and abused because of the belief that they relieve stress and anxiety. Some of them induce sleep, ease tension, cause relaxation or help users to forget their problems. They are sourced from valium, alcohol, promethazine, and chloroform.

e. Miscellaneous: This is a group of volatile solvents or inhalants that provide euphoria, emotional disinhibiting and ever-lasting distortion of thought to the user. The main sources are glues, spot removers, tube repair, perfumes, chemicals, etc.

f. Tranquilizers: Tranquilizers are believed to produce calmness without bringing drowsiness. They are chiefly derived from Librium, Valium among others.

\section{Statement of the Problem}

Increasing youth involvement in substance use and abuse is a major threat to national development, family stability and social security from which they need to be protected (Antwi, Adjei, Asare \&Twene, 2003). Studies by Kypri, Cronin and Wright (2005), Balogun, (2006), Nanchi, (2007), Melchior, Chastang, Goldberg and Fombonne (2008), (Fareo, 2012) and Adigun (2014) worked on drug abuse and drug effect related studies. None of the aforementioned researchers did their research work on the causes and consequences of drug abuse among undergraduates of the University of Ilorin. Therefore, this study uses different statistical tools and population. This is why the researcher deemed it fit to carry out research on the causes and consequences of drug abuse among undergraduates of the University of Ilorin, Kwara State, Nigeria.

\section{Research Questions}

1. What are the causes of drug abuse among undergraduates of University of Ilorin, Kwara State, Nigeria?

2. What are the consequences of drug abuse among undergraduates of University of Ilorin?

\section{Research Hypotheses}

Ho1: There is no significant difference in the causes of drug abuse among undergraduates of University of Ilorin on the basis of gender.

Ho2: There is no significant difference in the consequences of drug abuse among Undergraduates of University of Ilorin on the basis of gender. 
Ho3: There is no significant difference in the causes of drug abuse among undergraduates of University of Ilorin on the basis of faculty.

Ho4: There is no significant difference in the consequences of drug abuse among Undergraduates of University of Ilorin on the basis of faculty.

\section{Methodology}

The research design adopted for this study was a descriptive survey. Daramola (2006) described a descriptive survey as the systematic attempt to describe the characteristics of given population of area of interest factually. Since this study sought the opinion of undergraduates on causes and consequences of drug abuse among undergraduates using a questionnaire, a descriptive survey design was therefore considered appropriate for use. The population of this study consisted of the entire population of students at the University of Ilorin, while the sample was six hundred and seventy-two (672) undergraduates of the University. These respondents were randomly selected from sixteen faculties.

The instrument used for this study was a researcher-designed questionnaire. The questionnaire consisted of three main parts A, B and C. Section A dealt with the demographic data of the respondents which presents information on gender and faculty of the respondents. Section B on the other hand, consists of ten (10) items that sought information on the causes of drug abuse among undergraduates, while Section C consists of another ten (10) items on consequences of drug abuse among undergraduates. The validity of the instrument was determined through face and content approaches. This was done through expert in test construction and evaluation to determine the validity of the instrument. The researcher used a test re-test method of reliability. The instrument was administered twice at an interval of two weeks to the respondents that was not part of the study sample. Pearson Product Moment Correlation was used to correlate the score and it yielded a coefficient of 0.72 and the instrument was considered very reliable. Percentages were used to describe the demographic characteristics of the respondents and research questions one and two, while t-test and Analysis of Variance (ANOVA) were used to test the null hypotheses postulated for the study at 0.05 level of Significance.

\section{Results}

Demographic Description of the Respondents

The data presented in Table 1 shows the demographic characteristics of the respondents using percentage. 
Table 1: Distribution of the Respondents by Students Gender, Faculty and Age

\begin{tabular}{lrr}
\hline Variables & Frequency & Percentage (\%) \\
\hline Gender & & \\
Male & 275 & 40.9 \\
Female & 397 & 59.1 \\
Total & $\mathbf{6 7 2}$ & $\mathbf{1 0 0 . 0}$ \\
& & \\
Faculty & & \\
Physical Science & 44 & 6.5 \\
Environmental Science & 37 & 5.5 \\
Education & 133 & 19.8 \\
Basic Medical Science & 32 & 4.8 \\
Management Science & 41 & 6.1 \\
Engineering and Technology & 36 & 5.4 \\
Information and communication & 36 & 5.4 \\
Agriculture & 36 & 5.4 \\
Arts & 36 & 5.4 \\
Veterinary Medicine & 35 & 5.2 \\
College of Medicine & 35 & 5.2 \\
Clinical Science & 43 & 6.4 \\
Life Science & 31 & 4.6 \\
Social Science & 27 & 4.0 \\
Law & 35 & 5.2 \\
Pharmacy & 35 & 5.2 \\
Total & $\mathbf{6 7 2}$ & $\mathbf{1 0 0 . 0}$
\end{tabular}

\section{Source: Author's Computation (2018)}

Table 1 reveals that out of the 672 respondents that participated in the study, 275 representing $40.9 \%$ of the respondents were males while 391 representing $59.1 \%$ of the respondents were females. This implies that there were more female respondents than male counterparts. In addition, it reveals that out of the 672 respondents that participated in the study, 44 representing $6.5 \%$ of the respondents were from faculty of Physical Science, 37 representing $5.5 \%$ of the respondents were from faculty of Environmental Science, 133 representing $19.8 \%$ of the respondents were from faculty of Education, 32 representing $4.8 \%$ of the respondents were from faculty of Basic Medical Science, 41 representing $6.1 \%$ of the respondents were from faculty of Management Science.

Others included Engineering and Technology with 36 representing 5.4\% of the respondents, Information and Communication, Agriculture and Arts with 35 representing 5.2\% of the respondents, were from faculty of Veterinary Medicine, College of Medicine, Law and Pharmacy, 43 representing $(6.4 \%)$ of the respondents were from faculty of Clinical Science, 31 representing $(4.6 \%)$ of the respondents were from faculty of Life Science, 27 representing $(4.0 \%)$ of the respondents were from faculty of Social Science. This shows that majority of the respondents in this study were from the Faculty of Education. 


\section{Answering the Research Questions}

Two research questions were raised for this study. Research questions 1 and 2 were answered using a mean rating, while the hypotheses were tested with the use of the independent t-test and One-way Analysis of Variance (ANOVA) statistical tools.

Research Question 1: What are the causes of drug abuse among undergraduates of University of Ilorin?

Table 2: Mean and Rank Order on the Causes of Drug Abuse among Undergraduates of University of Ilorin

\begin{tabular}{clcc}
\hline S/N & \multicolumn{1}{c}{ Items } & Mean & Ranking \\
\hline 5 & The need to cope with academic challenges & 3.00 & $\mathbf{1}^{\text {st }}$ \\
4 & Ignorance about dangers inherent in drug abuse & 2.99 & $\mathbf{2}^{\text {nd }}$ \\
3 & Societal acceptance of some drugs e.g. alcohol & 2.90 & $\mathbf{3}^{\text {rd }}$ \\
6 & Experience of parents' drug use and abuse & 2.81 & $\mathbf{4}^{\text {th }}$ \\
9 & The need to cope with academic challenges & 2.76 & $\mathbf{5}^{\text {th }}$ \\
1 & Peer group influence & 2.70 & $\mathbf{6}^{\text {th }}$ \\
2 & Lack of parental care & 2.48 & $\mathbf{7}^{\text {th }}$ \\
7 & Desire to feel popular among colleagues & 2.46 & $\mathbf{8}^{\text {th }}$ \\
10 & High level of poverty & 2.39 & $\mathbf{9}^{\text {th }}$ \\
8 & Media influence i.e. social media & 2.38 & $\mathbf{1 0}^{\text {th }}$ \\
\hline
\end{tabular}

Table 2 indicates that the major causes of drug abuse among undergraduates of University of Ilorin was the need to cope with academic challenges which has a mean score of 3.00 and ranked $1^{\text {st }}$ followed by Ignorance about dangers inherent in drug abuse which has a mean score of 2.99 and ranked $2^{\text {nd }}$. Societal acceptance of some drugs such as alcohol which has a mean score of 2.90 was ranked $3^{\text {rd }}$, experience of parents' drug use and abusewhich has a mean score of 2.81 was ranked $4^{\text {th }}$. The need to cope with academic challenges which has a mean score of 2.76 and ranked $5^{\text {th }}$, peer group influence which has a mean score of 2.70 and ranked $6^{\text {th }}$, while other statements have mean score below 2.50 benchmark. This implies that ignorance about dangers inherent in drug abuse is the most cause of drug abuse among undergraduates of the University of Ilorin.

Research Question 2: What are the consequences of drug abuse among undergraduates of University of Ilorin? 
Table 3: Mean and Ranking Order on the Consequences of Drug Abuse among Undergraduates of University of Ilorin

\begin{tabular}{clcc}
\hline S/N & \multicolumn{1}{c}{ Items } & Mean & Ranking \\
\hline 7 & Low self-esteem & 3.51 & $\mathbf{1}^{\text {st }}$ \\
8 & Destabilized future ambition & 3.15 & $\mathbf{2}^{\text {nd }}$ \\
6 & Social isolation (i.e. poor relationship with others) & 3.06 & $\mathbf{3}^{\text {rd }}$ \\
9 & Attributed to crime & 2.96 & $\mathbf{4}^{\text {th }}$ \\
5 & Poor health (depression) & 2.89 & $\mathbf{5}^{\text {th }}$ \\
4 & Psychological disorder & 2.87 & $\mathbf{6}^{\text {th }}$ \\
10 & Violence and unstable & 2.83 & $\mathbf{7}^{\text {th }}$ \\
3 & Dropping out of school & 2.77 & $\mathbf{8}^{\text {th }}$ \\
2 & Poor relationship with teachers & 2.40 & $\mathbf{9}^{\text {th }}$ \\
1 & Poor academic performance & 2.17 & $\mathbf{1 0}^{\text {th }}$ \\
\hline
\end{tabular}

Table 3 shows that the main consequences of drug abuse among undergraduates of University of Ilorin was low self-esteem which has a mean score of 3.51 and ranked $1^{\text {st }}$ followed by destabilized future ambition which has a mean score of 3.15 and ranked $2^{\text {nd }}$, social isolation such as poor relationship with otherswith the mean score of 3.06 ranked $3^{\text {rd }}$, attributed to crime which has a mean score of 2.96 was ranked $4^{\text {th }}$, whilepoor health (depression) which has a mean score of 2.89 and ranked $5^{\text {th }}$, psychological disorder which has a mean score of 2.87 and ranked $6^{\text {th }}$, violence and unstable which has a mean score of 2.83 was ranked $7^{\text {th }}$, dropping out of school which has a mean score of 2.77 and ranked $8^{\text {th }}$, while other statement have mean score below 2.50 benchmark.

\section{Hypotheses Testing}

Having considered the demographic data of the respondents and answering the research questions, the researcher proceeded to test the null hypothesis postulated for the study.

Ho1: There is no significant difference in the causes of drug abuse among undergraduates of University of Ilorin based on gender.

In order to test this research hypothesis, responses of the respondents on the causes of drug abuse questionnaire were collated based on gender. The data collected from the study were analyzed as shown in Table 4. 
Table 4: Mean, Standard Deviation and t-test Analysis of Difference in the Causes of Drug Abuse among Undergraduates of the University of Ilorin based on Gender

\begin{tabular}{lllccccc}
\hline Gender & N & Mean & SD. & Df & Cal.t & Sig. & Decision \\
\hline Male & 275 & 26.72 & 9.29 & & & & Ho1 \\
& & & & 670 & 0.34 & 0.74 & $\begin{array}{c}\text { Not } \\
\text { Rejected }\end{array}$
\end{tabular}

Female $\quad 397 \quad 26.95 \quad 8.84$

As shown in Table 4 that the calculated t-value was 0.34 , while the sig. value is 0.74 based on the df 670 at alpha level of 0.05 . On this basis, null hypothesis one was therefore not rejected. This means that there was no significant difference in the causes of drug abuse among undergraduates of the University of Ilorin based on gender. The reason was that the calculated sig. value (0.74) was greater than 0.05 alpha level $(\rho>0.05)$.

Ho2: There is no significant difference in the consequences of drug abuse among undergraduates of University of Ilorin based on gender.

In order to test this research hypothesis, responses of the respondents on the consequences of drug abuse questionnaire were collated based gender. The data collected from the study were analyzed as shown in Table 5.

Table 5: t-test Analysis on theDifference in the Consequences of Drug Abuse among Undergraduates of University of Ilorin Based on Gender

\begin{tabular}{lccccccc}
\hline Gender & N & Mean & SD. & df & Cal.t & Sig. & Decision \\
\hline Male & 275 & 28.70 & 5.78 & & & & Ho2 \\
& & & & 670 & 0.33 & 0.74 & $\begin{array}{c}\text { Not } \\
\text { Rejected }\end{array}$ \\
Female & 397 & 28.55 & 5.46 & & & & \\
\hline
\end{tabular}

As shown in Table 5, the calculated t-value was 0.33 , while sig. value is 0.74 based on the df 670 at alpha level of 0.05 . On this basis, null hypothesis two was therefore not rejected. This means that there was no significant difference in the consequences of drug abuse among undergraduates of University of Ilorin based on gender. The reason was that the calculated significance value $(0.74)$ was greater than 0.05 alpha level $(\boldsymbol{\rho}>0.05)$. 
Ho3: There is no significant difference in the causes of drug abuse among undergraduates of University of Ilorin based on the faculty.

In order to test this research hypothesis, responses of the respondents on the causes of drug abuse questionnaire were collated based their faculty. The data collected from the study was analyzed as shown in Table 6.

Table 6: ANOVA Summary of Difference in the Causes of Drug Abuse among Undergraduates of University of Ilorin Based on Faculty

\begin{tabular}{lcccccc}
\hline $\begin{array}{l}\text { Source of } \\
\text { Variance }\end{array}$ & $\begin{array}{c}\text { Sum of } \\
\text { Squares }\end{array}$ & df & $\begin{array}{c}\text { Mean } \\
\text { Squares }\end{array}$ & F & Sig. & Decision \\
\hline $\begin{array}{l}\text { Between } \\
\text { Groups }\end{array}$ & 6.024 & 15 & 2.008 & & & H03 \\
Within Groups & 54646.262 & 656 & 81.806 & & & $\begin{array}{c}\text { Not } \\
\text { Rejected }\end{array}$ \\
Total & $\mathbf{5 4 6 5 2 . 2 8 6}$ & $\mathbf{6 7 1}$ & & & & \\
\hline
\end{tabular}

Table 6 shows that F-value 0.025 with calculated Sig. 0.995 at 0.05 alpha level. Since calculated significance 0.995 is greater than 0.05 alpha level, hypothesis three is thus not rejected. This implies that there was no significant difference in the causes of drug abuse among undergraduates of University of Ilorin based on their faculty.

Ho4: There is no significant difference in the consequences of drug abuse among undergraduates of University of Ilorin based on faculty.

In order to test this research hypothesis, respondent's responses on the consequences of drug abuse questionnaire were collated based faculty. The data collected from the study was analyzed as shown in Table 7.

Table 7: ANOVA Summary of Difference in the Consequences of Drug Abuse among Undergraduates of University of Ilorin Based on Faculty

\begin{tabular}{lcccccc}
\hline $\begin{array}{l}\text { Source of } \\
\text { Variance }\end{array}$ & $\begin{array}{c}\text { Sum of } \\
\text { Squares }\end{array}$ & df & $\begin{array}{c}\text { Mean } \\
\text { Squares }\end{array}$ & F & Sig. & Decision \\
\hline $\begin{array}{l}\text { Between } \\
\text { Groups }\end{array}$ & 33.550 & 15 & 11.183 & & & H04 \\
Within Groups & 20906.079 & 656 & 31.297 & 0.357 & 0.784 & $\begin{array}{c}\text { Not } \\
\text { Rejected }\end{array}$ \\
Total & $\mathbf{2 0 9 3 9 . 6 2 9}$ & $\mathbf{6 7 1}$ & & & & \\
\hline
\end{tabular}


Table 7 shows an F-value 0.357 with calculated significant 0.784 at 0.05 alpha level. Since calculated significance 0.784 is greater than 0.05 alpha level, hypothesis four is thus not rejected. This implies that there was no significant difference in the consequences of drug abuse among undergraduates of the University of Ilorin based on their faculty.

\section{Discussion}

The findings of this study revealed that the major cause of drug abuse among undergraduates at the University of Ilorin was the need to cope with academic challenges. This finding is in line with that of Ibrahim, Mahmud, Abubakar, Harazimi and Abdulkadir (2016) who found that unemployment and a low level of education also played a role in drug abuse.

Another finding revealed that the main consequences of drug abuse among undergraduates of University of Ilorin was low self-esteem. This finding is similar to Njeru and Lewis (2014) who reported that poor performance is the greatest effect of drug and substance abuse among secondary school students in Dagoretti Division, Nairobi West District-Kenya. Also, Ibrahim, Mahmud, Abubakar, Harazimi and Abdulkadir (2016) reported that memory losses, school attendance, difficulty in concentration, poor performance were some of the educational consequences in drug abuse.

Findings further revealed that there was no significant difference in the causes of drug abuse among undergraduates of University of Ilorin based on gender. This finding is incongruent with that of Ibrahim, Mahmud, Abubakar, Harazimi and Abdulkadir (2016) who revealed there was a significant difference in the causes of drug abuse among youth on the basis of gender. Interestingly, Akanbi, Godwin, Anyio, Muhammad and Ajiboye (2015) reported that there was a significant impact of substance abuse on academic performance among adolescent students of Colleges of Education in Kwara State, Nigeria on the basis of gender.

Furthermore, findings revealed that there was no significant difference in the causes of drug abuse among undergraduates of University of Ilorin based on faculty. This finding is in line with that of Abdu-Raheem (2013) who reported that there was no significant difference in sociological factors related to drug abuse among secondary school students' academic performance in Ekiti and Ondo States, Nigeria on the basis of subject area. Additionally, findings revealed that there was no significant difference in the consequences of drug abuse among undergraduates of University of Ilorin based on faculty. This finding supports that of AbduRaheem (2013) who reported that there was no significant difference in the effects of drug abuse on secondary school students' academic performance in Ekiti and Ondo States, Nigeria on the basis of their disciplines.

\section{Conclusion}

The findings of this study revealed that the major causes of drug abuse among undergraduates of University of Ilorin was the need to cope with academic challenges. Findings also revealed that the main consequences of drug abuse among undergraduates of the University of Ilorin was low self-esteem. Findings further revealed that there was no significant difference in the causes of drug abuse among undergraduates of University of Ilorin based on gender and their faculty. In addition, findings revealed that there was no significant difference in the consequences of drug abuse among undergraduates of University of Ilorin based on gender and faculty. 


\section{Recommendations:}

The following recommendations were made based on the findings of the study.

1. The government should enact measures on people that are selling drugs indiscriminately and they should be supervising the target area at least monthly if possible and also check the activities of the victims of drug abuse.

2. The Ministry of Education in conjunction with the National Campaign Against Drug Abuse (NACADA) should engage in appropriate interagency agreements in order to streamline the provision of services to support students with social and behavioural problems emanating from drug abuse.

3. School administrators should develop, implement and regularly review, in consultation with the school community and governing council, a school behavioural code which is consistent with the drug abuse policies.

4. Parents and caregivers should have access to drug abuse information, support materials and related documents and be aware of their rights to advocacy and of avenues open to them should they have grievances relating to the school's management of student's behavior.

5. Teachers should develop and foster positive relationships with students and families; communicate and interact effectively with students. 


\section{References}

Abdu-Raheem, B. O. (2013). Sociological factors to drug abuse and the effects on secondary school students' academic performance in Ekiti and Ondo States, Nigeria. Contemporary Issues in Education Research - Second Quarter, 6(2), 18 .

Adegboro J. S. (2014). Drug abuse among students of Adekunle Ajasin University, AkungbaAkoko, Ondo State, Nigeria.International Journal of Education and Research, 2 (4), 29-36.

Adegboyega, L. O., Oniye, A. O. \& Adigun, A. (2015). Motivations for drug abuse among students of tertiary institutions in Kwara State, Nigeria. Ife Journal of Behavioural Research, 7(1\&2), 29-34. (A Journal of the Department of Educational Foundations and Counselling, Obafemi Awolowo University, IleIfe, Nigeria); ISSN 2141-3770.

Adegboyega, L. O., Yahaya, L A., Alwajud-Adewusi, M. B. \& Aminu, H. P. (2016). Manifestation of depression among undergraduate students in Kwara State, Nigeria: Implications for counselling. IIUM Journal of Educational Studies, 4(2), 85-96. (A Journal of the Kulliyyah of Education, International Islamic University, Malaysia). Available online at http://journals.iium.edu.my/ijes/index.php/iejs/article/view/122/pdf_39

Adigun, A. A. (2014). Prevalence of, and motivation for drug abuse among students of tertiary institutions in Kwara State. Unpublished M.Ed Project, Department of Counsellor Education, University of Ilorin, Ilorin, Nigeria.

Akanbi, M. I., Godwin, A., Anyio, B. T., Muhammad, M. \& Ajiboye, S. A. (2015). Impact of substance abuse on academic performance among adolescent students of Colleges of Education in Kwara State, Nigeria. Journal of Education and Practice, 6(28), 108 - 112.

Atoyebi, O. A. \&Atoyebi, O. E. (2013). Pattern of substance abuse among senior secondary school students in a Southwestern Nigerian City. International Review of Social Sciences and Humanities, 4 (2) 54-65.

Balogun, S.K. (2006). "Chronic intake of separate and combined alcohol and nicotine. Center for Disease Control (CDC, 2000). HIV/AIDS: Frequently asked questions on HIV/AIDS. from www.cdenpin.org/hiv/faq/preventionJitm

Chukwuka, C.O. (2015). Truancy among Secondary School Students in Eboniyi South Education Zone. Retrieved on $20^{\text {th }}$ September, 2017 from http://www.doublegist.com

Durani, Y. (2012). Getting the facts: Drugs and alcohol. Retrieved from http://www.kids heath.org/teens/drugsandalcohol.htm.educational performance of some adolescents' drug abusers in Ibadan". 
Ekpenyong, S. N. (2012). Drug abuse in Nigerian schools: A study of selected secondary iinBayelsa State, South-South, Nigeria. International Journal of Scientific Research in Education, 5 (3), 260-268.

Ekpo, A. U. (1981). Marijuana is very harmful. Nigerian Gong, pp. 9-11.

Enakpoya, E. (2009). "Prevalence of drug abuse among Nigerian adolescents: Enugu: J.J. Classic Publishers Ltd

Encyclopedia (2004). Vol. 6, Chicago: World Book.

Erikson, E. H (1974). Identity youth and crisis. London: Feber and Feber.

Escandon, R., \& Galvez, C. (2006). Free from addictions. Madrid: Editorial safeliz.

Ehindero, S. A. (2015). Truancy among public Secondary School Students: Implication for Counseling. Journal of Emerging trends in Education Research and Policy Studies, 6 (7), 331- 338.

Eremie, M. D. (2015). Counsellors and teachers ranking of factors truancy among Secondary School in Rivers State, Nigeria. Arabian Journal of Business and Management Review, 5 (163), 25 - 35.

Eskiner, E. \&Gedif, T. (2006).Prevalence of khat, cigarette and alcohol use among students of Technology and Pharmacy, Addis Ababa University. Ethiopian Pharmaceutical Journal, 24, 116-124.

Henriksson, C. \&Leifman, H. (2012). School children's drug habit in 2012. Report No. 133.

Ibrahim, H. A. Mahmud, S. Abubakar, A. Harazimi, C. \&Abdulkadir, S. (2016). Effect of drug abuse among youth and its impact on learning. IOSR Journal of Pharmacy and Biological Sciences (IOSR-JPBS), 11(1), 14 - 17.

Johnston, L. D. \& O’Malley, P. M. (2001). Drug use and abuse: psychosocial aspects. In: International Encyclopaedia Social \& Behavioural Sciences, 3861-3866, Ann Arbor, Michigan, USA.

Kumesa, S. T., Mohammed, M. A., Gebremariam, E. T., Gelaw, B. K., Seifu, M. F. \&Tirumurgan, G. (2015). The prevalence and pattern of social drug abuse among students of Rift Valley University College, Bishoftu Campus, 2014, Bishoftu, Ethiopia.Journal of Pharma Care Health System, 2 (1), 1-7.

Kypri, K., Cronin, M. \& Wright, C. S. (2005). Do university students drink more hazardously than their non-student peers? Addiction, 100,713-4.

Lagos: Drug Demand Reduction Unit, National Drug Law Enforcement Agency.

Maloma, F. (2017). Factors influencing drug abuse among in-school adolescents in Ilorin metropolis. An unpublished B.Ed. Project, Department of Counsellor Education, Institute of Education, University of Ilorin, Ilorin, Nigeria. 
McNeely, C. A. \& Barber, B. K. (2010). How do parents make adolescents feel loved? Perspectives on supportive parenting from adolescents in 12 cultures.Journal of Adolescent Research, 25, 601-663

Melchior, M., Chastang, J. F., Goldberg, P. \& Fombonne, E. (2008). High prevalence rates of tobacco, alcohol and drug use in adolescents and young adults in France: results from the GAZEL Youth study. Addict Behaviour, 33, 122-33.

Merki, B. (1996). Teen health, decision for healthy living. New York: McGraw-Hill.

Mousavi F., Garcia, D., Jimmefors, A., Archer, T. \& Ewalds-Kvist, B. (2014). Swedish high-school pupils' attitudes towards drugs in relation to drug usage, impulsiveness and other risk factors. Peer Journal,2, e410.

NAFDAC (2004). A hand book on prevention of drugs and substance abuse in Nigeria. Abuja: NAFDAC.

NAFDAC (2008). Do drugs control your life? Know the risks. Abuja: NAFDAC.

Njeru, A. N. \& Lewis, N. (2014). Causes and effects of drug and substance abuse among secondary school students in Dagoretti Division, Nairobi West DistrictKenya. Global Journal of Interdisciplinary Social Sciences, 3(3), 1 - 4.

Nyaga, P. (2001). Unpublished seminar paper on substance abuse presented at Nakuru High school during the NakuruSUb county Mathematics and Science in-service course for teachers. Nakuru.

Olatunde, A. (1979). Self-medication: Benefits, precautions and dangers, London: on body maintenance among Albinorats", Journal of Human Ecology, 19(1) 21 24.Organization Expert Committee on Dependence Producing Drugs. Fourteenth.

Oriahi, I. F., Ajekweneh, M. \& Oriahi, C. I. (2010). Causes and effects of drug abuse among secondary school adolescent in Esan West Local Government, Edo state, Nigeria. Retrieved from http://www.injoprado.com/html.

Perkinson, R. R. (2002). Chemical dependency counselling. California: Sage Publication.

Santrock, W. (2001). Adolescent problems. New York: McGraw Hill Co ltd.

Schuster, C., O’Malley, P. M., Bachman, J. G., Johnston, L. D. \&Schulenberg, J. (2001). Adolescent marijuana use and adult occupational attainment: A longitudinal study from age 18 to 28. Use Misuse, 36,997-1014

Seraphim T, (2005). Addiction is also pharmacological. Retrieved from http://www.meadowlake

Simatwa, E. M. W., Odhong, S. O., Juma, S. L. A. \& Choka, G. M. (2014). Substance abuse among public secondary school students: Prevalence, strategies and challenges for public secondary school Managers in Kenya: A case study of Kisumu East Sub County.Educational Research, 5 (8), 315-330. 
Stanton, B., Li, X., Cottrell, L. \& Kaljee, L. (2001). Early initiation of sex, drug-related risk behaviours, and sensation-seeking among urban, low-income AfricanAmerican adolescents. Journal of National Medical Association, 93, 129- 138.

Thomas, M. \& Allen, A. (2009). Religiosity, spirituality, and substance abuse. A published M.Sc. Thesis, Department of Criminal Justice in the Graduate School of. The University of Alabama.

Tsering, D., Pal, R. \& Dasgupta, A. (2010). Substance use among adolescent high school students in India: A survey of knowledge, attitude, and opinion. Journal of Pharm Bioallied Science, 2 (2), 137-140.

UNDCP (1996). Drugs and development: The social impact of drug abuse. Viena: UNDCP. undergraduates. World Journal of Medical Sciences. 1(2), 133-139.

Undergraduates: A case study of the Obafemi Awolowo University, Ile-Ife,

UNICEF \& WHO (2006). Global school-based health survey report. Geneva. WHO. Retrieved from http://www.who.int/chp/gshs/UNICEF-GSHC-Report-Oct07.pdf.

United Nations Office on Drugs and Crime (UNODC, 2011). World drug report, United Nations, New York.

United Nations Organizations on Drug Council (UNODC) (2005). "World Health

UNODC (2012). World drug report. United Nations Office on Drugs and Crime, Vienna,10-18.

UNODC (2014). World drug report. New York: United Nations publication, 11-25. 